\title{
PEMITRA BAGI PENGEMBANGAN KEMAMPUAN MATEMATIKA GURU DAN SISWA SEKOLAH DASAR MUHAMMADIYAH PROGRAM KHUSUS DI BOYOLALI
}

\author{
Sutama, Sabar Narimo, dan Suyatmini \\ Fakultas Keguruan dan Ilmu Pendidikan \\ Universitas Muhammadiyah Surakarta \\ Email : sutama@ums.ac.id
}

\begin{abstract}
Abstrak
Dalam membelajarkan matematika diperlukan suatu metode pelajaran yang dapat mengubah persepsi matematika yang sulit menjadi matematika yang menyenangkan. Metode mathmaster merupakan metode dalam membelajarkan matematika yang menekankan pada pemahaman konsep dengan peraga mainan atau media lain yang sesuai dengan dunia anak sehingga pembelajaran lebih menyenangkan dan bermakna. Tujuan dari kegiatan ini, yaitu 1) Guru-guru Sekolah Dasar Muhammadiyah Program Khusus di Boyolali, memahami dan menguasai metode math master dalam pembelajaran matematika; 2) Siswa-siswa Sekolah Dasar Muhammadiyah Program Khusus di Boyolali tidak lagi memiliki Numeric phobia terhadap pelajaran matematika; 3) Siswa-siswa Sekolah Dasar Muhammadiyah Program Khusus di Boyolali memiliki peningkatan dalam pengetahuan dan keterampilan berhitung (matematika) dari sebelumnya. Metode pelaksanaan ini melalui tiga tahap, yaitu workshop, implementasi, dan evaluasi metode math master. Hasil pelaksanaan kegiatan: 1) Guru-guru Sekolah Dasar Muhammadiyah Program Khusus di Boyolali menggunakan metode math master dalam membelajarkan matematika; 2) ) Siswasiswa Sekolah Dasar Muhammadiyah Program Khusus di Boyolali tidak lagi memiliki Numeric phobia, hal ini dikarenakan guru menggunakan alat peraga atau media lain yang menunjang dalam pembelajaran matematika sehingga siswa lebih mudah dalam memahami konsep matematika; 3) Ada peningkatan hasil belajar matematika setelah adanya implementasi metode math master.
\end{abstract}

Kata Kunci : kemampuan, math master, numeric phobia

\begin{abstract}
In learning mathematics requires a method of learning that can change difficult mathematical perceptions into a fun math. Math master method is a method in learning mathematics that emphasizes the understanding of the concept with the visual display or other media in accordance with the world of children so that learning is fun and meaningful. The purpose of this activity, 1) Teachers of Muhammadiyah Primary School Special Program in Boyolali, understand and dominate the method of math master in mathematics learning; 2) Students of Muhammadiyah Primary School Special Program in Boyolali do not have numeric phobia against mathematics lessons; 3) Students of the Muhammadiyah Primary School Special Program in Boyolali have an increase in numerical knowledge and skills (mathematics). The implementation method of this activity through three stages were workshop, implementation, and evaluation of math master method. The results of the implementation of activities:
\end{abstract}




\begin{abstract}
1) The teachers of Muhammadiyah Primary School Special Program in Boyolali using math master method in mathematics learning; 2)) Students of Muhammadiyah Primary School Special Program in Boyolali do not have numeric phobia, because teachers used visual display or other media that support in mathematics learning so that students more easily understand the concept of mathematics; 3) There is an increase in mathematics learning outcomes after the implementation of math master methods.
\end{abstract}

Keywords : ability, math master, numeric phobia

\section{Pendahuluan}

Menatap masa depan yang serba terbuka, penguasaan matematika sangat penting. Penguasaan matematika dibutuhkan untuk mengantisipasi perkembangan Ilmu Pengetahuan dan Teknologi (IPTEK). Kehidupan era industri modern yang ditandai dengan kehadiran dan perkembangan Teknologi Informasi dan Komunikasi (TIK) dalam dunia kerja menuntut pembelajaran matematika di tingkat satuan pendidikan menyesuaikan diri dengan perkemba-ngan IPTEK. Hal tersebut mempunyai makna bahwa perlunya rancangan pembelajaran matematika yang tidak hanya membekali siswa untuk melanjutkan ke pendidikan yang lebih tinggi, akan tetapi juga membekali siswa untuk memasuki dunia pasar kerja. Pengembangan pembelajaran matematika harus dipersiapkan dengan matang, dan dihasilkan dari kerjasama serta pertimbangan stakeholders.

Semua tidak bisa memungkiri bahwa hasil tes penelitian yang dilakukan oleh Trend In Internasional Matematic and Sciences Study (TIMSS) menempat Indonesia untuk kemam-puan matematika rangking 38 dari 42 Negara (Napitupulu, Kompas 14/12/2012). Keterpurukan hasil ini semakin diperkuat oleh hasil survei Programme for International Student Assesment (PISA) terbaru tahun 2015 yang menempatkan kemampuan literasi matematika siswa Indonesia pada peringkat 63 dari 70 negara (OECD, 2016: 5). Berdasarkan hasil survey Internasional tersebut membuktikan bahwa matematika menjadi pelajaran paling ditakuti oleh pelajar di Indonesia.
Salah satu permasalahan dalam dunia pendidikan terutama pendidikan dasar (elementary school) terkait pembelajaran matematika, yaitu neumeric phobia (takut pada pelajaran berhitung). Neumeric phobia dapat diartikan sebagai penyakit yang sudah menjangkau semua lapisan masyarakat dan seluruh lapisan pelaku dunia pendidikan baik itu guru dan murid bahkan hingga tataran pengambil kebijakan pada dunia pendidikan. Hal ini pula yang terjadi pada siswa Sekolah Dasar (SD) Muhammadiyah Program Khusus (PK) di Kecamatan Boyolali dan Banyudono. Kegamangan serta ketidaktertarikan terhadap pelajaran matematika terjadi di lingkungan SD mitra tersebut.

Hasil observasi awal di SD mitra tersebut memberikan hasil, antara lain: (1) guru dalam membelajarkan matematika hanya menekankan pada pengembangan pengetahuan yang bersifat fakta dan ingatan, serta melupakan aspek proses dan konteks; (2) guru dalam membelajarkan matematika belum memperhatikan kemampuan awal siswa; (3) guru belum melaksanakan pembelajaran matematika bermakna, metode yang digunakan juga kurang bervariasi, dan sebagai akibatnya komunikasi dan koneksi belajar matematika sulit ditumbuhkan dan pola belajar matematika cenderung menghafal. Akibatnya, hasil belajar matematika masih di bawah mata pelajaran lain yang diujikan dalam Ujian Akhir Sekolah Berstandar Nasional (UASBN).

Keberhasilan dalam pembelajaran matematika bukan karena suatu hal yang secara kebetulan, melainkan karena usaha yang terprogram secara seksama. Sutama 
(2016) menjelaskan bahwa guru sebagai ujung tombak di lapangan mempunyai peranan yang sangat menentukan dalam peningkatan mutu pendidikan. Hal senada dijelaskan oleh Susanto (2012) yang menyatakan bahwa performance guru salah satunya dipengaruhi oleh kompetensi pedagogik. Guru bertanggung jawab untuk mengatur, mengarahkan, dan menciptakan suasana yang mendorong siswa belajar sebagai kebutuhan. Guna menunjang tugas guru yang berat ini, perlu adanya kerja sama terus menerus antara dosen LPTK dengan mitra guru SD dalam mengatasi masalah yang muncul dalam pembelajaran, khususnya matematika.

Halyangperludilakukanuntukmengatasi kesulitan siswa dalam belajar matematika yaitu membangun ketertarikan dan kemauan untuk belajar dan berlatih memecahkan masalah matematika (Santosa, Waluya, \& Sukestiyarno, 2012: Nawi, 2012). Alternatif tindakan yang bisa ditawarkan berdasarkan permasalahan di SD Muhammadiyah PK di Kecamatan Boyolali dan Banyudono sebagai sekolah mitra, yaitu perlunya inovasi dalam pembelajaran matematika. Inovasi yang dapat dilakukan diantaranya dengan menerapkan pembelajaran math master.

Math master merupakan salah satu metode dalam membelajarkan matematika. Pem-belajaran dengan metode mathmaster adalah proses belajar dan mengajar matematika mulai dari pemahaman konsep dengan peraga mainan yang sesuai dengan dunia anak sehingga proses belajar mengajar lebih menyenangkan (Saifudin \& Muhtadi, 2010). Math master merupakan cara pengajaran dan pendekatan konsepkonsep dasar Aritmetika yang mudah dan menyenangkan, serta menjadi landasan/ pondasi dalam pembelajaran matematika secara menyeluruh.

Terdapat tiga strategi dasar yang harus dikuasai dengan baik, terutama bagi pendidik dalam menerapkan math master. Pertama, pemahaman konsep merupakan hal mutlak yang harus dikuasai oleh setiap pendidik. Melalui penguasaan pemahaman konsep yang baik, pendidik dapat memahamkan konsep kepada siswa dengan baik pula. Kedua, kemampuan mengaplikasikan konsep sangat ditentukan bagaimana konsep itu dipahami dan sejauh mana konsep itu dipahami. Pengulangan dan pemantapan aplikasi akan menjadikan proses dalam membelajarkan matematika terasa mudah. Ketiga, keterampilan dalam mengaplikasikan konsep tidak hanya berhenti pada sejauh mana siswa bisa, akan tetapi harus sampai pada tingkat siswa terbiasa. Hal tersebut dapat dimaknai bahwa dalam membelajarkan matematika tidak berhenti sampai pada jawaban siswa benar, akan tetapi berapa waktu yang dibutuhkan siswa untuk menyelesaikan soal dengan benar.

Metode pembelajaran math master bertujuan untuk merubah persepsi, siswa, guru dan masyarakat terhadap matematika dari menakutkan menjadi pelajaran yang menyenangkan, bahkan menjadi permainan yang mengasyikkan. Melalui implementasi metode math master SD Muhammadiyah PK di Boyolali ini diharapkan terjadi peningkatan atas capaian hasil belajar matematika yang berdampak pada meningkatnya hasil ujian akhir semester maupun hasil UASBN.

\section{Metode Pelaksanaan}

Kegiatan pengabdian masyarakat ini dilakukan dalam tiga tahap, yaitu workshop metode math master oleh tim kepada guru matematika, implementasi metode math master di sekolah, dan evaluasi metode math master. Pada tahap pertama, guru diberikan sosialisasi dalam bentuk kegiatan workshop oleh tim ahli math master sebagai salah satu upaya untuk mengembangkan kemampuan profesional, pedagogik, dan prinsip kolegialitas dalam pening-katan kualitas pembelajaran. Tahap ini memberikan ruang bagi guru untuk melakukan diskusi bersama tim math master terkait permasalahan pembelajaran di kelas, dan alternatif pemecahannya. Dari hasil identifikasi masalah dan diskusi perencanaan pemecahannya, selanjutnya dikemas dalam suatu perangkat pembelajaran yang terdiri atas: (1) rencana 
pelaksanaan pembelajaran (RPP); (2) materi ajar; (3) lembar kerja siswa (LKS) atau media pembelajaran; (4) instrumen penilaian proses dan hasil pembelajaran; serta (5) lembar observasi pembelajaran.

Tahapan kedua dari pelaksaan metode math master, yaitu implementasi metode math master di sekolah. Kegiatan yang dilakukan pada tahap ini, yaitu guru membelajarkan matematika dengan metode math master. Selain itu, guru memilih siswa yang unggul dalam mata pelajaran matematika untuk diberikan bimbingan lebih lanjut dan dipersiapkan dalam olimpiade di tingkat Kabupaten maupun Nasional. Siswa yang terpilih tersebut juga dipersiapkan untuk menjadi tentor bagi siswa lain yang mengalami kesulitan dalam belajar matematika. Tahapan yang ketiga, yaitu evaluasi terkait implementasi metode math master. Kegiatan yang dilakukan pada tahap ini, yaitu diskusi bersama antara pelaksana kegiatan, tim math master, guru matematika, dan siswa yang menjadi mentor terkait capaian hasil belajar matematika dengan metode math master.

\section{Hasil dan Pembahasan}

Serangkaian pembelajaran matematika dengan metode math master telah dilakukan dalam tiga tahap. Pada tahap pertama, guru diberikan sosialisasi dalam bentuk kegiatan workshop oleh tim ahli math master sebagai salah satu upaya untuk mengembangkan kemampuan profesional, pedagogik, dan prinsip kolegialitas dalam peningkatan kualitas pembelajaran. Peserta kegiatan ini, yaitu guru-guru matematika SD Muhammadiyah PK se-Kabupaten Boyolali. Kegiatan dilakukan di SD Muhammadiyah PK pada tanggal 10-11 Maret 2017. Tahap kedua dilaksanakan pada 13 Maret sampai dengan 13 Mei 2017. Tahap ketiga dilaksanakan pada 19-20 Juni 2017. Secara rinci kegiatan dalam masing-masing tahapan dijelaskan sebagai berikut.

\section{Tahap pertama: workshop math master oleh tim ahli}

Kegiatan workshop math master bagi guru matematika SD Muhammadiyah PK se-Kabupaten Boyolali berlangsung dua hari, yaitu hari Jum'at dan Sabtu tanggal 10-11 Maret 2017 di SD Muhammadiyah PK Banyudono. Kegiatan ini diikuti oleh 35 guru matematika SD Muhammadiyah di Kabupaten Boyolali. Kegiatan workshop ini dipandu oleh pelaksana kegiatan beserta tim ahli math master.

Kegiatan workshop berlangsung mulai jam 08.00-15.00. Selama kegiatan berlangsung para guru mendiskusikan permasalahan-permasalahan yang muncul dalam pembelajaran matematika. Tim ahli math master menggali lebih dalam tentang permasalahan yang dihadapi oleh para guru. Setelah dilakukan pendalaman lebih jauh guru mengakui bahwa adanya kesalahan dalam pemahaman konsep dasar, seperti $13 \times 6=13+13+13+13+13+13$. Guru juga mengakui bahwa pembelajaran matematika yang dilakukan selama ini belum dikaitkan dengan permasalahan kontekstual yang dijumpai siswa sehari-hari.

Pada kegiatan workshop, tim math master menjelaskan bahwa terdapat strategi dasar yang harus dikuasai oleh para guru matematika. Ada tiga strategi dasar yang harus dikuasai dengan baik, terutama bagi pendidik yang menerapkan math master, yaitu pemahaman konsep, aplikasi konsep, dan keterampilan aplikasi konsep. Pemahaman konsep, Kemampuan memahami konsep merupakan hal mutlak yang perlu dikuasai oleh setiap guru. Melalui pemahaman konsep yang baik, guru dapat memahamkan konsep secara baik pula kepada anak didiknya. Aplikasi Konsep, kemampuan dalam mengaplikasikan konsep ditentukan bagaimana konsep itu dapat dipahami, dan sejauh mana konsep tersebut dapat dipahami. Pengulangan dan pemantapan aplikasi ini akan menjadikan proses pembelajaran yang berlangsung terasa lebih mudah. Keterampilan aplikasi konsep, kemampuan mengaplikasikan konsep tidak hanya berhenti pada tingkat siswa bisa, akan tetapi lebih ditekankan pada tingkat terbiasa. Selain hal tersebut, keterampilan aplikasi 
konsep tidak berhenti hanya sampai jawaban benar saja, akan tetapi berapa waktu yang dibutuhkan siswa untuk menyelesaikan soal dengan benar.

Tim math master juga menyampaikan bahwa kebermaknaan dalam belajar matematika sangat penting, dan ada baiknya guru memperhatikan hal tersebut. Pembelajaran matematika akan lebih bermakna jika guru mampu menyajikan pembelajaran tersebut dalam bentuk kontekstual. Saat ini Indonesia berpartisipasi dalam studi Programme for International Student Assesment (PISA) sebanyak enam kali selama tahun 2000-2015. Namun, sejak pertama kali keikutsertaan ini, prestasi matematika siswa Indonesia belum menunjukkan hasil yang memuaskan. Pada kurun waktu 2003-2009 hampir 80\% siswa Indonesia hanya mampu mencapai level mengingat dan memahami dari enam level (mengingat, memahami, menerapkan, menganalisis, mengevaluasi, dan mencipta) soal yang diujikan PISA (Kemendikbud, 2012). Stacey (2010) menjelaskan bahwa pada PISA matematika tahun 2009, hampir semua siswa Indonesia hanya mencapai level menerapkan, sedangkan hanya $0,1 \%$ siswa Indonesia yang mampu mencapai level mengevaluasi dan mencipta. Keterpurukan hasil ini semakin diperkuat oleh hasil survei PISA terbaru tahun 2015 yang menempatkan kemampuan literasi matematika siswa Indonesia pada peringkat 63 dari 70 negara dengan pencapaian level yang masih terbilang rendah dimana hampir seluruh siswa Indonesia pada survey ini hanya mampu mencapai level menerapkan (OECD, 2016: 5).

Berdasarkan paparan tentang kebermaknaan dalam pembelajaran matematika di atas, tim ahli math master meminta guru untuk merenungkan dan memikirkan kembali tentang langkahlangkah yang bagaimana agar konsep matematika yang bersifat abstrak dapat dengan mudah dipahami oleh anak didiknya. Hal ini dikarenakan keberhasilan dalam pembelajaran matematika bukanlah suatu kebetulan, akan tetapi diperlukan perencanaan pembelajaran yang terprogram dan seksama dalam segala hal, termasuk mempersiapkan RPP, materi ajar, LKS atau media pembelajaran, instrumen penilaian proses dan hasil pembelajaran, serta lembar observasi pembelajaran untuk perbaikan dalam proses pembelajaran selanjutnya.

\section{Tahap kedua: implementasi metode math master di sekolah}

Setelah mendapatkan pelatihan dan pendampingan oleh tim pelaksana dengan melibatkan tenaga ahli math master, guru mengimplementasikan metode math master di sekolah masing-masing. Kegiatan tahap kedua ini berlangsung pada 13 Maret sampai dengan 13 Mei 2017. Kegiatan yang dilakukan pada tahap ini, yaitu guru membelajar-kan matematika dengan metode math master. Salah satu contoh implementasi metode math master yang digunakan guru dalam membelajarkan matematika ditunjukkan sebagai berikut.

Langkah pertama, guru dalam membelajarkan konsep perkalian menggunakan permasalahan kontekstual. Guru menanyakan pada siswa, "Apakah kalian sudah pernah melihat sapi". Jawaban siswa, "Sudah Bu Guru". Guru bertanya, "Berapa banyak kaki yang dimiliki sapi?". Siswa menjawab, "Sapi mempunyai empat kaki Bu". Selanjutnya guru memberikan permasalahan yang harus diselesaikan secara berkelompok (kelompok telah dibentuk secara heterogen oleh guru sebelumnya). Permasalahan tersebut, yaitu "Ada berapa buah kaki yang ada atau dimiliki oleh lima ekor sapi?".

Langkah kedua, guru menyiapkan beberapa alat peraga seperti manik-manik, sedotan minuman, lidi, dan kartu bergambar untuk membantu siswa menyelesaikan masalah dengan caranya sendiri. Guru meminta masing-masing kelompok untuk menuliskan jawaban dengan memberikan alasan diperolehnya jawaban dengan mengkomunikasikan-nya dengan siswa lain. Hasil jawaban kelompok pertama:siswa 
membilang satu per satu kaki dengan alat peraga yang ada.

Hasil jawaban kelompok kedua:siswa menuliskan di papan tulis $4+4+4+4+4$ $=5 \times 4=20$.

Langkah ketiga, guru membenarkan semua jawaban dan memberikan umpan balik kepada siswa berupa permasalahan, "Andaikan banyaknya kaki yang dimiliki 15 ekor sapi, apakah kita harus menghiting satu per satu kaki sapi yang ada?" sambil menunjuk jawaban kelompok satu. Bagaimana dengan jawaban kelompok dua?. Guru kemudian memperluas permasalahan, "Bagaimana jika kita disuruh menghitung ratusan atau bahkan ribuan ekor sapi?".

Langkah keempat, bertitik tolak dari jawaban siswa, guru mengajak siswa untuk mengubah penjumlahan berulang ke dalam bentuk perkalian (seperti jawaban kelompok dua).

Langkah kelima, guru dapat memberikan latihan atau soal-soal pada siswa berkaitan dengan mengubah bentuk penjumlahan berulang kedalam bentuk perkalian atau sebalik-nya untuk direnungkan.

Selain pembelajaran kontekstual yang dilaksanakan oleh guru pada pembelajaran di kelas, pada tahap ini guru memilih siswa yang unggul dalam mata pelajaran matematika untuk diberikan bimbingan lebih lanjut dan dipersiapkan dalam olimpiade di tingkat Kabupaten maupun Nasional. Selain itu, siswa yang terpilih tersebut dipersiapkan agar menjadi tentor bagi siswa lain yang mengalami kesulitan dalam belajar matematika diluar jam pelajaran di sekolah. Kegiatan ini bertujuan untuk memfasilitasi siswa yang memiliki ketakutan kepada guru untuk mengkomunikasikan permasalahan yang dihadapinya untuk dikomunikasikan kepada teman sejawatnya.

\section{Tahap ketiga: evaluasi pelaksanaan metode math master}

Tahap terakhir dalam pelaksanaan metode math master, yaitu evaluasi. Tahap evaluasi ini dilaksanakan pada 19-20 Juni 2017. Kegiatan pada tahap ini melibatkan pelaksana penelitian, tim math master, guru matematika, dan siswa terpilih. Pada kegiatan ini masing-masing perwakilan dari guru dan siswa menyampaikan kesannya terkait pembelajaran matematika dengan metode math master yang telah dilaksanakan. Siswa menyampaikan bahwa banyak teman-teman yang mengajak belajar kelompok untuk mendiskusikan permasalah matematika sepulang jam sekolah. Guru menyampai-kan bahwa adanya peningkatan hasil pembelajaran setelah dilaksanakannya metode math master. Pelaksana kegiatan selaku tim observer juga menyampaikan adanya pengaruh yang signifikan sebelum dan sesudah dilaksanakannya metode math master. Masing-masing uraian dalam kegiatan observasi dirangkum sebagai berikut.

Tabel 1 Kondisi Sebelum dan Sesudah Diimplementasikannya Math Master

\begin{tabular}{|c|c|c|}
\hline Uraian & $\begin{array}{l}\text { Kondisi sebelum } \\
\text { math mater }\end{array}$ & $\begin{array}{l}\text { Kondisi setelah } \\
\text { math master }\end{array}$ \\
\hline $\begin{array}{l}\text { Pemahaman konsep guru } \\
\text { terhadap matematika }\end{array}$ & $\begin{array}{l}\text { Kecenderungan guru belum } \\
\text { memperhatikan akan pema- } \\
\text { haman konsep yang benar. }\end{array}$ & $\begin{array}{l}\text { Semua guru memperhatikan akan } \\
\text { pemahaman konsep yang benar. }\end{array}$ \\
\hline Pembelajaran di kelas & $\begin{array}{l}\text { Monoton, hanya sebatas } \\
\text { menjelaskan materi, mem- } \\
\text { berikan contoh, dan mem-berikan } \\
\text { tugas. }\end{array}$ & $\begin{array}{l}\text { Menggunakan alat peraga, LKS, } \\
\text { atau media lain yang menunjang } \\
\text { pembelajaran. }\end{array}$ \\
\hline
\end{tabular}

Persepsi siswa terhadap Sulit, banyak rumus yang harus Rumus tidak harus dihafal, akan pelajaran matematika dihafal. tetapi dipahami. 
Nilai Ujian Akhir Semester

Nilai UASBN
Banyak siswa yang menda-patkan Kecenderungan siswa mennilai sebatas kriteria ketuntasan dapatkan nilai di atas KKM. minimum atau sebatas KKM.

Data tahun 2015/2016, nilai rata- Data tahun 2016/2017, nilai ratarata 7,55 dengan nilai tertinggi rata 8,35 dengan nilai tertinggi 9,50 . 100 .

\section{Simpulan}

Berdasarkan hasil pelaksanaan kegiatan, disimpulkan hal-hal berikut: 1) Kegiatan workshop math master mampu membenarkan pemahaman konsep guru yang keliru; Pembelajaran dengan metode math master mampu mengubah persepsi matematika yang sulit menjadi matematika yang menyenangkan sehingga numeric phobia dapat diminimalisir melalui metode pembelajaran ini; 3) metode math master mampu menciptakan suasana pembelajaran yang bermakna sehingga hal ini berdampak pada meningkatnya hasil belajar matematika siswa.

\section{Persantunan}

Kegiatan pengabdian ini dapat terlaksana dengan baik karena dukungan dari berbagai pihak. Penulis menyampaikan terimakasih kepada: 1) Direktorat Riset dan Pengabdian Masyarakat Direktorat Jenderal Penguatan Riset dan Pengembangan Kementerian Riset, Teknologi, dan Pendidikan Tinggi yang telah mendanai pengabdian ini. 2) Tim Pengabdi, rekan-rekan sejawat, dan mahasiswa yang telah membantu terlaksananya kegiatan pengabdian. 3) Guru-Guru Matematika SMP Muhammadiyah PK se-Kabupaten Boyolali yang telah berperan serta penuh dalam kegiatan.

\section{DAFTAR PUSTAKA}

Kemdikbud. 2012. Dokumen Kurikulum 2013. Jakarta: Kemdikbud.

Napitupulu, E. L. 2012. Prestasi Sains dan Matematika Indonesia Menurun. Harian Kompas, (14 Desember 2012) Diperoleh dari : http://edukasi.kompas.com.

Nawi, M. 2012. "Pengaruh Strategi Pembelajaran dan Kemampuan Penalaran Formal Terhadap Hasil Belajar Matematika Siswa Sekolah Menengah Atas (Swasta) Al Ulum Medan”. Jurnal Tabularasa PPs UNIMED, 9 (1), 81-96.

OECD. 2016. PISA 2015 Results in Focus. Paris: OECD Publishing.

Saifudin dan Muhtadi. 2010. Strategi Math Master Si Jago Matematika. Surakarta: PT Bahana Media Wirayuda.

Santosa, N., Waluya., S. B., \& Sukestiyarno. 2012. Kemampuan Pemecahan Masalah pada Pembelajaran Matematika dengan Strategi Master dan Penerapan Scaffolding. Unnes Journal of Mathematics Education Research, 2 (2), 69-75.

Stacey, K. 2011. The PISA View of Mathematical Literacy in Indonesia. Journal on MathematicsEducation (IndoMS-JME),2 (2), 95-126.

Susanto, H. 2012. Faktor-faktor yang mempengaruhi kinerja Guru Sekolah Menengah Kejuruan. Jurnal Pendidikan Vokasi, 2 (2), 1997-212.

Sutama. 2016. Darurat Pembelajaran Matematika: Guru Matematika Profesional untuk Menyiapkan Generasi Emas. Makalah disajikan pada Seminar Nasional Pendidikan Matematika pada tanggal 15 Mei 2016. 